\title{
The Study of Insects for Forensic Applications
}

\author{
A. Divya ${ }^{1}$, K. Bhoopathy Bagan ${ }^{2}$, S. Lincy Manimala ${ }^{3}$ \\ Department of Electronics Engineering ${ }^{1,2,3}$, Madras Institute of Technology ${ }^{1,2,3}$ \\ Email: adivyaece@mitindia.edu ${ }^{1}$,bhoopathybagan@annauniv.edu ${ }^{2}$, sslincymanimala@gmail.com ${ }^{3}$
}

\begin{abstract}
Forensic entomology is the study of insects in the successive pattern of anthropods with the developmental stages of different species in the dead body or decomposed cadavers for criminal and legal matters. It is the study of anthropod biology. It also involves the application of study of anthropods including insects, arachnids, centipedes, millipedes and crustaceans in criminal cases. It is used to detect the death composition of drug and poison activity in the particular incident and to find the presence or absence of insects at the time of the infliction of wounds. Forensic entomology is used in estimating the minimum post mortem time interval.
\end{abstract}

Index Terms-Anthropods; biology; cadavers; Entomology; Criminals

\section{FORENSIC ENTOMOLOGY}

Insect succession will decompose the body when it arrives at the cadaver position. It again undergoes physical, chemical and biological changes with different stages and different species of insect arrivals. Calliphoridae (Blowflies) and Sarcophagidae (Flesh Flies) arrive at the death posture within 24 hours by means of blood fluids or other body fluids. Piophilidae (Cheese Skippers) will not come into the fresh corpse and it arrive at the last stage of decomposition. Many insects will feed the body at different stage indirectly.

\section{INSECT GROWTH AND DEVELOPMENT}

Insects are belongs to a group called anthropods. Several characteristics will differentiate insects from other anthropods. Normally an insect structure is divided into many sections as head, thorax and abdomen. The insect body is initially segmented and the anthropods segments are divided into sections. The eyes, antennae and mouth parts are on the head, and the legs and wings are on the thorax. An insect skeleton is always present on the outside of its body and is called as an exoskeleton. It serves as a support for the anthropod (Calliphoridae) muscles and internal organs as well as a covering. The body wall of an insect has three layers. The outer layer of the anthropod cuticle containing chitin, proteins and often pigments. This anthropod cuticle is secreted mainly by a cellular layer of beneath and that layer is called as epidermis. The inner layer of the larvae growth is called the basement membrane. An insect has two types of mouth parts as chewing and sucking. Insects with sucking mouthparts suck the liquid foods through and elongated beak. Insects or blowflies with chewing mouthparts are tearing off pieces of host tissue and ingest it.

\subsection{Metamorphosis}

All insects have different development stages with different development time, which changes in the form are called as metamorphosis. Juvenline harmone control the development rate of head by the secretal glands in the insect. Insects will change its size according to their development period and that form of growth is called as simple metamorphosis. The young insect is called as nymps or larvae. Each insect live with different habitat activity and each differ from their appearance and this type of growth stage is called as complete metamorphosis.

\section{Types of insects}

\subsection{Blow Fly}

Blowflies are called with the Scientific name of Calliphoridae and it comes under the class of Insecta with the Animalia kingdom. It is an order of fly with higher classification name of Oestroidea. The first type of insect arrive at the dead body is Calliphoridae which is attracted by its body fluids and gases. It laid eggs in the corpse within half a day in natural opening or in a wound. Eggs will laid out in batches and hatch after a period of time and the first period of development of eggs is called First Instar Larvae. The larvae will feed on the corpse and again it started to develop to second larvae stage and then third larvae stage. The size of the larvae and the breathing spiracles of the larvae will determine the decomposition stage of the flesh for post mortem time interval calculation. The larva skin will turn into hard core of outer shell and it started to protect it as it metamorphoses into an adult. The pupae will develop into deep brown color. Each development of larvae will take a specific amount of time. Temperature is the important feature in the development of larvae because insects are cold blooded with increase in metabolic rate (i.e) development of larvae increases, as the temperature rises. 


\section{International Journal of Research in Advent Technology, Vol.7, No.5, May 2019 E-ISSN: 2321-9637 \\ Available online at www.ijrat.org}

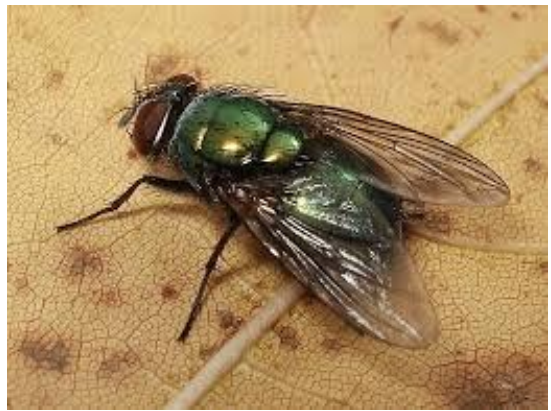

Fig. 1. Blowfly

\subsection{Beetle}

Beetles form a group of insects with the order and scientific name of Coleoptera with the class of Insecta and it comes under the Phylum Euarthropoda, kingdom of Animalia. It has an lifespan class of Callosobruchus maculatus of 10 to 14 days as development period and total lifetime of 3 to 6 months. Beetles are also used as medico legal field evidence with reference to dry human skeletal remains in the last stage of decomposition. Dermestidae (Skin beetles) and Cleridae (Bone beetles) will found on the decomposed body to estimate the post mortem time interval. DNA (RAPD) type of necrophagous insects have been used in the study of criminal forensic entomology. Skin beetles are generally $0.8 \mathrm{~mm}$ in length and it is small in size. These insects are usually oval in shape with pale grey chunkey beetls. These are also called as woolly bears or hairy beetles. It laid upto 150 eggs and hatch within out of 3 weeks. The larvae stage development will happen in 5 to 15 weeks depending upon the temperature and type of food it consumes.

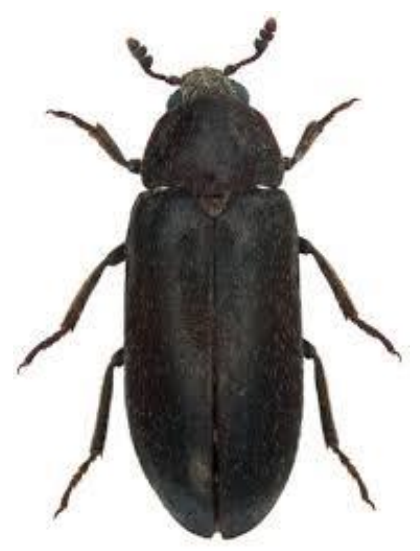

Fig. 2. Beetles

\subsection{Mites}

Mites are also a small anthropods belongs to the class Arachnida and the subclass of Acari. The term mite refers to the members of the several groups in Acari with the Phylum family of Arthropoda, kingdom of Animalia and subphylum of Chelicerata. The body of the mites is divided into two segments as the Cephalothorax or Prosoma and Opisthosoma(i.e.) there is no separate head. It comes under the scientific class of acarlogy. Mostly mites are tiny and it is less than 0.04 and $1 \mathrm{~mm}$ in length. Some of the mites live in water and some in soil decomposers. The eggs will laid in substrate and it will hatch in six weeks and the first stage of larvae has six legs. The development stages of mites is called as moults , after three stages of moults is called as nymphs with eight legs and again after three moults they become adults. These insects feed on animal, plants and living beings and it lives on fresh and salt water. Mites are harmless to the human beings and domestic animals. Decomposition of decaying organic material or fungi is a part of the carbon cycle. It acts as a vector for disease transmission or as allergic diseases. Mites will cause skin rashes and itches with scabies or skin orders.

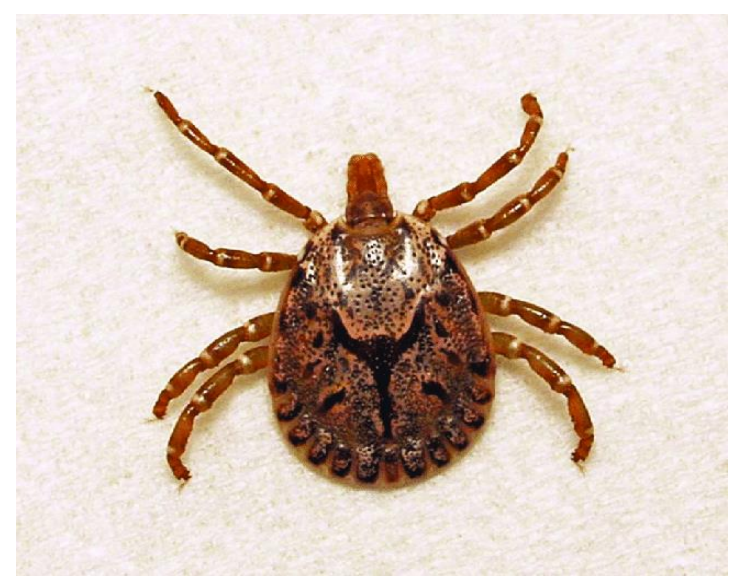

Fig. 3. Mites

\subsection{Flesh flies}

Family name of flies is Sarcophagidae and these are called as Flesh flies. These flies are totally different from other flies. These flesh flies will deposited in decaying materials such as carrions, open wounds, dung and mammals. It will hatch egg and while deposited on any material. It is in the kingdom of Animalia and Phylum of Arthropoda with the class of Insecta. It is in the order of Diptera. It is in the section of Schizophora with 


\section{Available online at www.ijrat.org}

Superfamily name of Oestroidea. The Adult flies will feed on fluids from blood animal's bodies or human cadavers and from other organic substances. It is normally small with a range limit of 0.16 to 0.9 inches with $(4.1$ to $22.9 \mathrm{~mm})$. Flesh flies maggot will feed for 3 to 4 days through three instars. It enters the intra puparial period in 10 to 14 days. The life time of a flesh fly is predictable. Different species will decompose the different stages. Forensic Entomologists will give the life cycle progress of larvae in many ways. The ambient temperature is measured for the growth of the larvae and it approximately estimates the date of death of the decomposed cadaver or animal. Flesh flies are closely related with humans (synanthropic) and colonize cadavers.

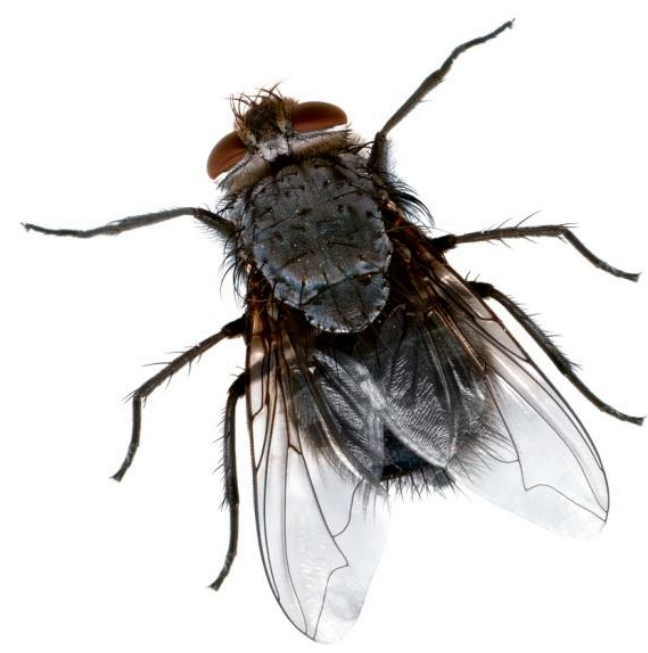

Fig. 4. Flesh fly

\subsection{Bugs}

Bugs are hexapod invertebrates; It is the largest group of insects in the arthropod phylum. The scientific name of Bugs is Insecta. It is a smallest insect which produces high amount of bacteria in the colonized bodies of animals or humans after the decomposition stage. Bugs are also used as evidence in both the criminal and civil cases. This type of criminal field used in the insect growth is called as medico legal entomology or medico criminal entomology. It focuses majorly in the violent crime scenes to determine the post-mortem time interval of human death and the particular location of death. Bugs found in the human body areas of eyes, nose, mouth, ears and it arrive very quickly in the decomposed area. Insects will arrive at the location by its smell and fluid level and the expiration of some insects is called as carrion insects. The body will start to decompose by means of generation of bugs rather than flies. Adult carrion will laid eggs inside of the body and it started to decompose by its inner level of human body. In the bug's development stage, the first stage of bug growth is egg and the second stage is the larvae growth and the third level is pupa development. It is grow fastly by feeding on the dead body. It is increase in the protein level of the bug intrapuparial period.

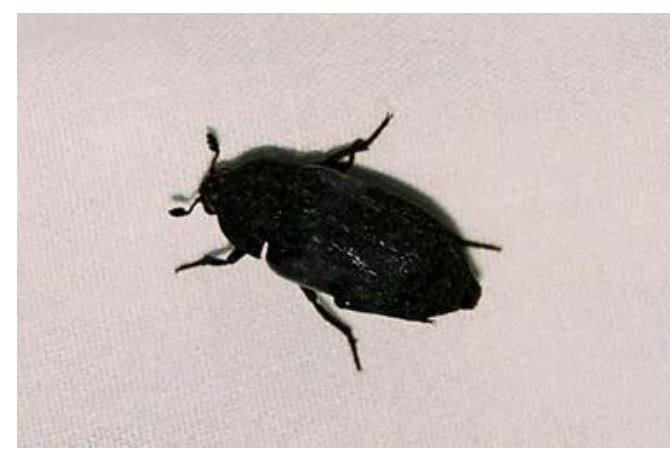

Fig. 5. Bugs

\section{DEVELOPMENT STAGES OF ALL INSECTS}

Table 1. Instars of all insects

\begin{tabular}{|c|c|c|c|}
\hline Insects & Eggs & Larvae & Pupa \\
\hline Blowfly & $\begin{array}{l}200 \text { to } 300 \\
\text { eggs within } \\
\text { half a day }\end{array}$ & $\begin{array}{l}4 \text { to } 5 \text { days } \\
\text { (Three } \\
\text { Instars) }\end{array}$ & 6 to 11 days \\
\hline Beetles & $\begin{array}{l}60 \text { eggs } \\
\text { within two } \\
\text { days }\end{array}$ & $\begin{array}{l}4 \text { to } 19 \text { days } \\
30 \text { stages as } \\
\text { one larvae }\end{array}$ & 9 months \\
\hline Mites & $\begin{array}{l}20 \text { eggs per } \\
\text { day }\end{array}$ & 2 to 3 days & 5 days \\
\hline Flesh flies & $\begin{array}{l}300 \text { eggs } \\
\text { within two } \\
\text { days }\end{array}$ & 3 to 4 days & $\begin{array}{l}10 \text { to } 14 \\
\text { days }\end{array}$ \\
\hline Bugs & $\begin{array}{l}500 \text { eggs } \\
\text { within one } \\
\text { lifetime ( } 5 \\
\text { eggs per } \\
\text { day) }\end{array}$ & $\begin{array}{l}6 \text { to } 10 \text { days } \\
\text { ( Five } \\
\text { Instars) }\end{array}$ & $\begin{array}{l}11 \text { to } 37 \\
\text { days }\end{array}$ \\
\hline
\end{tabular}

\section{PRESERVATION OF INSECTS}

Forensic investigation will rely mainly on the evidence and materials found at the investigation place. It is very hard to find the insect in the 
investigation place but it is quickly identified in the decomposed death area. Temperature is important in the particular place. Entomologist will take many samples from different areas of the body.

Human body will be at fresh state and it undergoes to dry stage in a matter of weeks and months and it fully depends on the geographic area with temperature dependent.

The insect collected from the death area is preserved in $80 \%$ of alcohol and the insects found in the same death area are killed by hot water and then preserved properly for the future use of estimation of post mortem time interval in case of death of animals or human body.

\section{REFERENCES}

[1]. Apichat, Vitta,; Chinnapat, Thaipakdee,; Kabkaew, Sukontason, L.; Kom, Sukontason,; Nophawan Bunchu,; Sangob Sanit; (2012),: Morphology and Developmental Rate of the Blow Fly, Hemipyrellia ligurriens (Diptera: Calliphoridae): Forensic Entomology Applications, pp.1-10.

[2]. Attila Trajer, J.(2018),: Which Mosquitoes (Diptera: Culiccidae) are candidates for DNA extraction in forensic practice?.

[3]. Wayne, Lord, D.; William, Rodriguez, C.; (1989),: Forensic Entomology: The Use of Insects in the Investigation of Homicide and Untimely Death, pp. 41- 48.

[4]. Christine, Picard, J.; Clinton, Carroll,; Darren, Dixon, A.; John, Goodpaster, V.; William, Kranz; (2017),: Factors Affecting Species Identification of Blow Fly Pupae Based upon Chemical Profiles and Multivariate Statistics, pp. 1-15.

[5]. Nazni, Wasi, Ahmad,; Nur, Atiqah, Arifuddin,; Rumiza, Abd, Rashid,; (2012),: Blowfly, Chrysomya Megacephala as An Alternative Specimen in Determination of Gunshot Residue, pp. 542-547.

[6]. Pushpa, Eliza,; Raja, Zuha, M.; (2018),: Preliminary Assessment of cephalopharyngeal skeleton length and body length of Hemipyrellia ligurriens (Wiedemann)(Diptera : Calliphoridae) larvae as potential parameters to estimate minimum post mortem interval, pp. 17.

[7]. Martin, Villet, H.; Rozane, Badenhorst,; (2018),: The uses of Chrysomya Megacephala (Fabricius, 1794)(Diptera: Calliphoridae) in forensic entomology, pp.2-15.

[8]. Catts, E., P.; Goff, M., L.; (1992),: Forensic Entomology in criminal investigations, vol.37, no. 1, pp. 253-272.
[9]. Lee, H., L.; (1996),: Recovery of forensically important insects larvae from human cadavers in Malaysia, Vol. 18, no. 2, pp. 125-127.

[10]. Kanchai, C.; Narongchai, P.; Sukontason, K.; (2007),: Forensic entomology cases in Thailand: a review of cases from 2000 to 2006, vol. 101, no. 5, pp. 1417-1423.

[11]. Ngern-Klun, R.; Sripakdee, D.; Sukontason, K.; Sukontasan, K., L.; (2007),: Identifying fly puparia by clearing technique: application to forensic entomology, vol. 101, no. 5, pp. 1407-1416.

[12]. Chowanadisai, L.; Kurahashi, H.; (2001),: Blowflies (Insecta: Diptera: Calliphoridae) from Indochina, vol. 6, pp. 185-242.

[13]. Erzinclioglu, Y., Z.; (1989),: The value of chorionic structure and size in the diagnosis of blowfly eggs, vol. 3, no. 3, pp. 281-285.

[14]. Bunchu, N.; (2012),: Blowfly (Diptera: Calliphoridae) in Thailand: distribution, morphological identification and medical importance appraisals, vol. 4, no. 1, pp. 57-64.

[15]. Adams, Z., J., O.; Hall, M., J., R.; (2003),: Methods used fro the killing and preservation of Blowfly larvae, and their effect on post mortem larval length, vol. 138, no. 1-3, pp. 5061. 